Pure \& Appl. Chem., Vo1.51, pp.2171-2182.

Pergamon Press Ltd. 1979. Printed in Great Britain.

FREE RADICAL MECHANISMS IN COORDINATION CHEMISTRY

\title{
Jack Halpern
}

Department of Chemistry, The University of Chicago, Chicago, Illinois 60637, U.S.A.

Abstract - Transition metal complexes exhibit several distinctive types of reactions leading to the formation of free radicals, notably:

$$
\begin{aligned}
& \mathrm{L}_{n} \mathrm{M} \cdot+\mathrm{RX} \longrightarrow \mathrm{L}_{n} \mathrm{M}-\mathrm{X}+\mathrm{R} \cdot \\
& \mathrm{L}_{n} \mathrm{M}-\mathrm{R} \longrightarrow \mathrm{L}_{n} \mathrm{M} \cdot+\mathrm{R} \cdot \\
& \mathrm{L}_{n} \mathrm{M}-\mathrm{H}+\mathrm{Z}=\mathrm{C}^{\prime}-\longrightarrow \mathrm{L}_{n} \mathrm{M} \cdot+\mathrm{H}-\mathrm{C}-\mathrm{C}^{\prime}
\end{aligned}
$$

The thermodynamic, kinetic and mechanistic aspects of these reactions and their roles in homogeneous catalysis are discussed.

\section{INTRODUCTION}

The theme of free radical mechanisms in coordination chemistry is an old one as manifested by such long familiar examples as the catalytic roles of metal salts (cobalt, manganese, copper, etc.) in the autoxidation of organic compounds. However, research and developments in the fields of coordination chemistry and of homogeneous catalysis during the past several decades have tended to deemphasize this theme and to focus for the most part, instead, on processes such as hydrogenation, carbonylation, hydroformylation and certain oxidation reactions which proceed through non-radical mechanisms of the type depicted in Table 1, namely mechanisms involving organometallic intermediates (typically 16- or 18-electron species) and characteristic sequences of "twoelectron" component steps such as oxidative addition, migratory insertion and reductive elimination $(1-4)$. The emphasis on such processes has been reinforced by the highly novel chemistry associated with them, as well as by important and distinctive applications, notably homogeneous catalytic processes of unusual selectivity such as asymmetric catalytic hydrogenation (5). In view of this, it is noteworthy that some of the most recent developments in the fields of homogeneous catalysis and coordination chemistry have once again focussed attention on free radical mechanisms and suggest that such mechanisms are more important and widespread than previously suspected, not only in new contexts but also in the context of processes, for example certain hydrogenation and hydroformylation reactions, that have previously been interpreted in terms of non-radical mechanisms (6-9). The present paper describes and discusses some of these developments and their implications.

\section{GENERATION OF FREE RADICALS BY REACTIONS OF METAL COMPLEXES}

Three distinctive and widespread processes in which free radicals are generated through reactions of metal complexes are depicted schematically by eqs. 1,2 and 3 , respectively.

$$
\begin{aligned}
& \mathrm{L}_{n} \mathrm{M} \cdot+\mathrm{R}-\mathrm{X} \longrightarrow \mathrm{L}_{n} \mathrm{M}-\mathrm{X}+\mathrm{R} \cdot \\
& \mathrm{L}_{n} \mathrm{M}-\mathrm{R} \longrightarrow \mathrm{L}_{n} \mathrm{M} \cdot+\mathrm{R} \cdot \\
& \mathrm{L}_{n} \mathrm{M}-\mathrm{H}+\mathrm{C}^{-\mathrm{C}^{\prime}} \longrightarrow \mathrm{L}_{n} \mathrm{M} \cdot+\mathrm{H}=\mathrm{C}-\mathrm{C}^{\prime}
\end{aligned}
$$


TABLE 1. Proposed non-radical mechanisms for some homogeneous catalytic processes.

$\mathrm{Rh}\left(\mathrm{PPh}_{3}\right)_{3} \mathrm{C}$-CATALYZED HYDROGENATION OF OLEFINS $\left(\mathrm{P}=\mathrm{PPh}_{3}\right)$

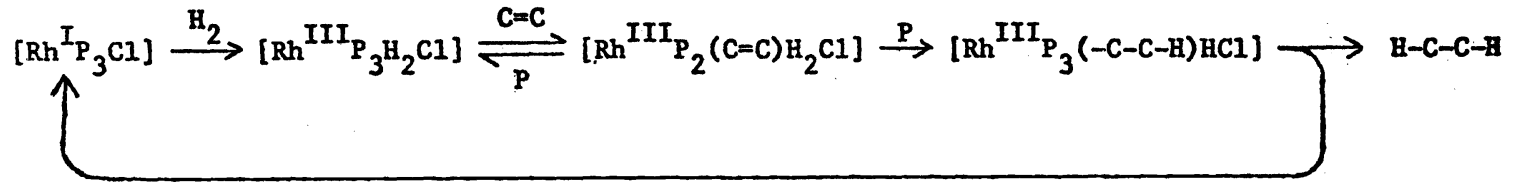

HYDROFORMYLATION OF OLEFINS (OXO PROCESS)

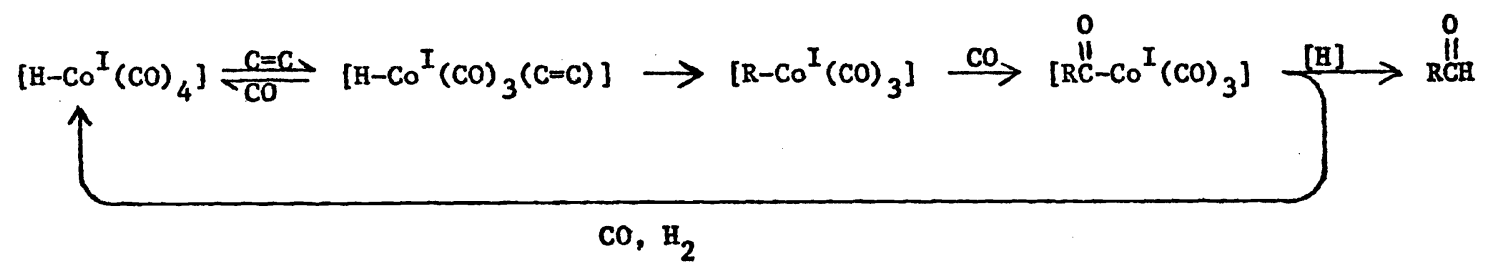

CARBONYLATION OF METHANOL TO ACETIC ACID

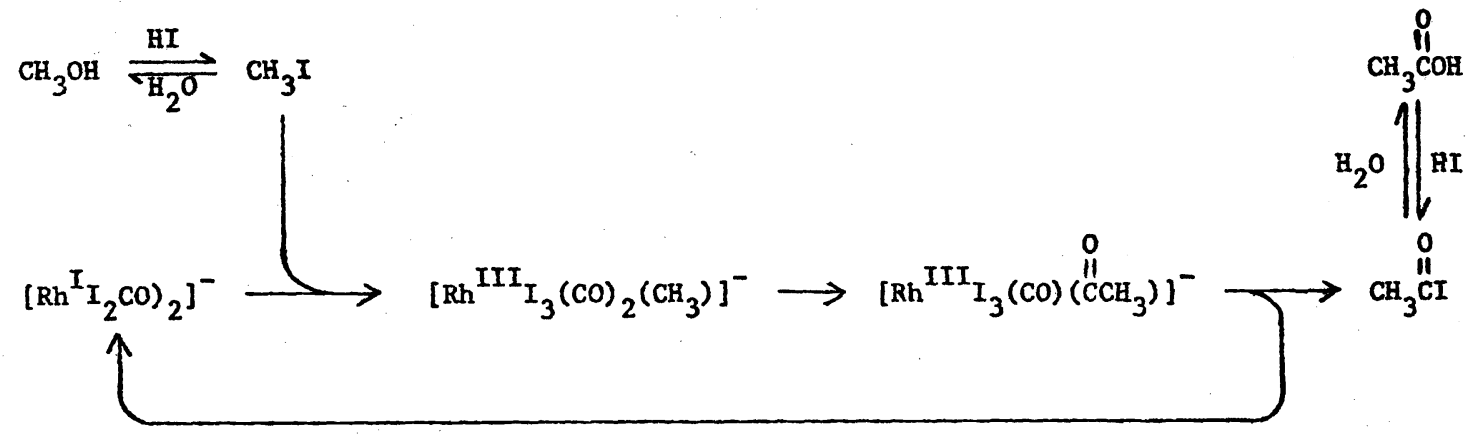

PALLAUIUM CHLORIDE-CATALYZED OXIDATION OF OLEFINS (WACKER FROCESS)

$$
\underbrace{\left[\mathrm{Pd}^{\mathrm{II}} \mathrm{Cl}_{4}\right]^{2-} \underset{\mathrm{CI}}{\stackrel{\mathrm{C}_{2} \mathrm{H}_{4}}{\rightleftharpoons}}\left[\mathrm{Pd}^{\mathrm{II}} \mathrm{Cl}_{3}\left(\mathrm{CH}_{2}=\mathrm{CH}_{2}\right)\right]^{-} \underset{\mathrm{H}^{+}}{\stackrel{\mathrm{H}_{2} \mathrm{O}}{\rightleftharpoons}}\left[\mathrm{Pd}^{\mathrm{II}} \mathrm{Cl}_{3}\left(\mathrm{CH}_{2} \mathrm{CH}_{2} \mathrm{OH}\right)\right]^{2-} \rightarrow\left[\mathrm{Pd}^{\mathrm{O}}\right]+\mathrm{CH}_{3} \mathrm{CHO}^{-}}_{\mathrm{O}_{2}, \mathrm{HCl}}
$$


The first of these processes reflects the characteristic free-radical-1ike reactivities associated with certain complexes having unpaired electrons, notably 17-electron low-spin pentacoordinate complexes such as those of cobalt(II). The facile occurrence of the second type of process reflects the characteristic "weakness" of metal-alkyl sigma-bonds. Correspondingly, the facile occurrence of the third type of process, as well as of analogous reactions involving $\mathrm{H}$ atom transfer from metal hydride complexes to other unsaturated organic molecules such as arenes, reflects the characteristic weakness of metal-hydrogen bonds. These themes and their applications are elaborated below.

\section{GENERATION OF FREE RADICALS BY REACTIONS OF ORGANIC HALIDES WITH LOW-SPIN COBALT(II) COMPLEXES}

Although analogous reactions have been observed for other metal complexes, for example of chromium(II) (10), processes of the type depicted by eq. 1 have been investigated most extensively for low-spin cobalt(II) complexes, in the first instance pentacyanocobaltate(II) $(11,12)$ and, subsequently, for bis(dioximato-) and for Schiffs base cobalt(II) complexes (13-15). The characteristic reactions of pentacyanocobaltate(II) with methyl and benzyl halides are depicted by the scheme of eqs. 4-6, in which the initial halogen abstraction step (eq. 4$)$ is rate-determining $(11,12)$.

$$
\begin{aligned}
& {\left[\mathrm{Co}(\mathrm{CN})_{5}\right]^{3-}+\mathrm{R}-\mathrm{X} \stackrel{\mathrm{k}_{4}}{\longrightarrow}\left[\mathrm{X}-\mathrm{Co}(\mathrm{CN})_{5}\right]^{3-}+\mathrm{R} .} \\
& {\left[\mathrm{Co}(\mathrm{CN})_{5}\right]^{3-}+\mathrm{R} \cdot \stackrel{\text { FAST }}{\longrightarrow}\left[\mathrm{R}-\mathrm{Co}(\mathrm{CN})_{5}\right]^{3-}}
\end{aligned}
$$

$$
\text { OVERALL REACTION: } 2\left[\mathrm{Co}(\mathrm{CN})_{5}\right]^{3-}+\mathrm{R}-\mathrm{X} \longrightarrow
$$

$$
\left[\mathrm{X}-\mathrm{Co}(\mathrm{CN})_{5}\right]^{3-}+\left[\mathrm{R}-\mathrm{Co}(\mathrm{CN})_{5}\right]^{3-}
$$

For radicals containing $\beta$-hydrogen atoms such as ethyl or isopropyl, $\beta$-hydrogen abstraction by [Co(CN) 5 ] $3-$ competes with combination of $R$. and [Co(CN) $]^{3-}$ resulting in the formation of $\left[\mathrm{H}-\mathrm{Co}(\mathrm{CN})_{5}\right]^{3-}$ and olefin through parallel paths as depicted below. For $\mathrm{R}=\mathrm{C}_{2} \mathrm{H}_{5}, \mathrm{k}_{8 \mathrm{a}} / \mathrm{k}_{8 \mathrm{~b}} \sim 4$ (12).

$$
\begin{aligned}
{\left[\mathrm{Co}(\mathrm{CN})_{5}\right]^{3-}+\mathrm{C}_{2} \mathrm{H}_{5} \mathrm{X} \stackrel{\mathrm{k}_{7}}{\longrightarrow}\left[\mathrm{X}-\mathrm{Co}(\mathrm{CN})_{5}\right]^{3-}+\mathrm{C}_{2} \mathrm{H}_{5} . } \\
\stackrel{\left.\mathrm{Co}(\mathrm{CN})_{5}\right]^{3-}+\mathrm{C}_{2} \mathrm{H}_{5} \cdot \longrightarrow}{\stackrel{\mathrm{k}_{8 \mathrm{a}}}{\longrightarrow}\left[\mathrm{C}_{2} \mathrm{H}_{5}-\mathrm{Co}(\mathrm{CN})_{5}\right]^{3-}}\left[\mathrm{H}-\mathrm{Co}(\mathrm{CN})_{5}\right]^{3-}+\mathrm{CH}_{2}=\mathrm{CH}_{2}
\end{aligned}
$$

Finally, when $\left[\mathrm{Co}(\mathrm{CN})_{5}\right]^{3-}$ is reacted with organic halides in the presence of [H-Co(CN) $]^{3-}$, efficient trapping of $\mathrm{R}$. by $\mathrm{H}$-atom abstraction from the metal hydride occurs (eq. 9), resulting in the catalytic cycle depicted by eqs. 4 , 9 and 10 .

$$
\begin{aligned}
& {\left[\mathrm{Co}(\mathrm{CN})_{5}\right]^{3-}+\mathrm{R}-\mathrm{X} \longrightarrow\left[\mathrm{X}-\mathrm{Co}(\mathrm{CN})_{5}\right]^{3-}+\mathrm{R} \cdot} \\
& \mathrm{R} \cdot+\left[\mathrm{H}-\mathrm{Co}(\mathrm{CN})_{5}\right]^{3-} \stackrel{\text { FAST }}{\longrightarrow}\left[\mathrm{Co}(\mathrm{CN})_{5}\right]^{3-}+\mathrm{R}-\mathrm{H}
\end{aligned}
$$

$$
\left[\mathrm{H}-\mathrm{Co}(\mathrm{CN})_{5}\right]^{3-}+\mathrm{R}-\mathrm{X} \longrightarrow\left[\mathrm{X}-\mathrm{Co}(\mathrm{CN})_{5}\right]^{3-}+\mathrm{R}-\mathrm{H}
$$


The reactions whereby the free radicals $R$ - are consumed in these systems, i.e. eqs. $11-13$ (where $L_{n} M \cdot=\left[\mathrm{Co}(\mathrm{CN})_{5}\right]^{3}$ - for the cases cited) are all sufficiently fast that they compete effectively with the radical coupling process, $2 \mathrm{R}$. $R_{2}$, and no formation of $R_{2}$ can be detected. From such competition studies it can be deduced that reactions $11-13$ must all proceed at rates that are close to diffusion-controlled and that the activation barriers for such reactions do not exceed a few $\mathrm{kcal} / \mathrm{mole}$.

$$
\begin{aligned}
& \mathrm{L}_{n} \mathrm{M} \cdot+\mathrm{R} \cdot \longrightarrow \mathrm{L}_{n} \mathrm{M}-\mathrm{R} \\
& \mathrm{L}_{n} \mathrm{M} \cdot+\mathrm{RCH}_{2} \mathrm{CH}_{2} \cdot \longrightarrow \mathrm{L}_{n} \mathrm{M}-\mathrm{H}+\mathrm{RCH}=\mathrm{CH}_{2} \\
& \mathrm{R} \cdot+\mathrm{L}_{n} \mathrm{M}-\mathrm{H} \longrightarrow \mathrm{R}-\mathrm{H}+\mathrm{L}_{n} \mathrm{M} \cdot
\end{aligned}
$$

It should be noted that reactions (11) and (12) correspond to the reverse of reactions (2) and (3), respectively. Hence, the activation enthalpy ( $\Delta H^{\ddagger}$ ) of each of the two latter processes (i.e., eqs. 2 and 3 ) is expected to be close to the corresponding enthalpy of reaction $\left(\Delta \mathrm{H}^{\circ}\right)$ as depicted in Fig. 1 .

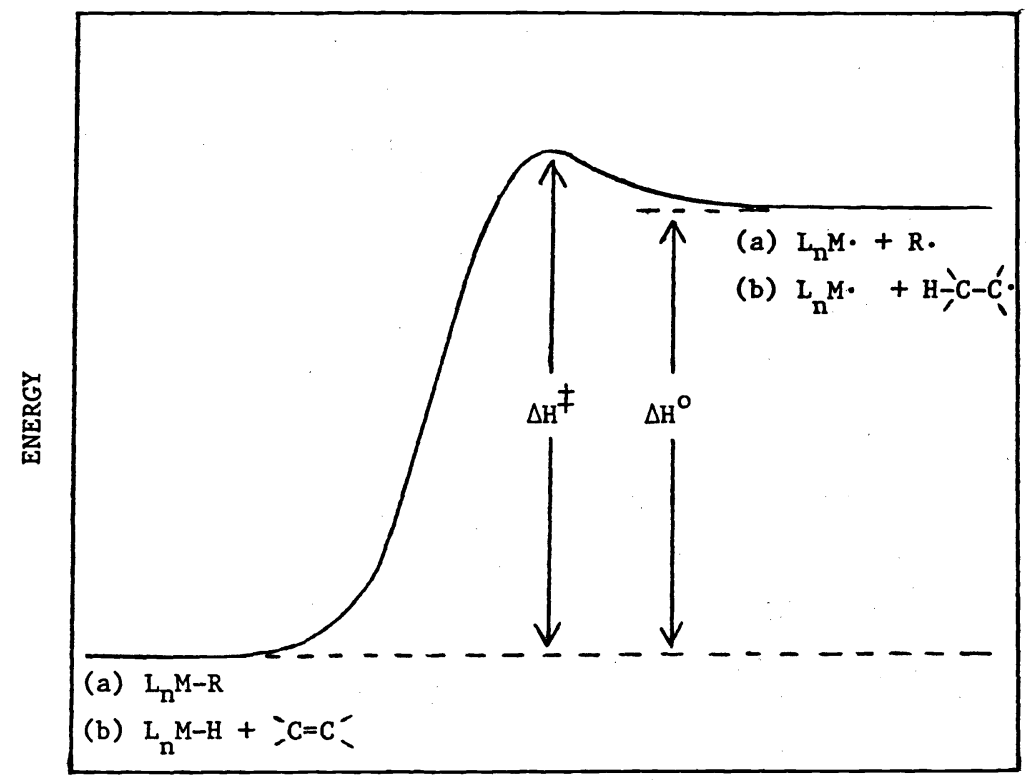

REACTION COORDINATE

Fig. 1. Schematic energy profiles for (a) reaction (2) and (b) reaction (3).

\section{HOMOLYTIC DISSOCIATION OF METAL-ALKYL BONDS}

Reliable data concerning metal-alkyl bond dissociation energies are very sparse (16). For binary (homoleptic) alkyls of the type $\mathbf{M R}_{\mathfrak{m}}$, mean bond dissociation energies can be deduced from heats of formation of the parent compounds. Such data, summarized in Table 2, are fairly accessible for stable non-transition metal alkyls such as $\mathrm{PbR}_{4}, \mathrm{SnR}_{4}$ and $\mathrm{HgR}_{2}$, and have recently been determined for a few transition metal alkyls, e.g., Ta $\left(\mathrm{CH}_{3}\right)_{5}$ and $\mathrm{W}\left(\mathrm{CH}_{3}\right)_{6}$. Typical mean metal alkyl bond dissociation energies in compounds of this type are fairly low, commonly in the range $30-40 \mathrm{kcal} / \mathrm{mole}$. While this reflects on the general weakness of metal-carbon sigma bonds, there may be considerable discrepancies between such mean bond dissociation energies and the corresponding individual bond dissociation energies in the same compounds, e.g., $\mathrm{D}_{\mathrm{CH}_{3}} \overline{\mathrm{Hg}-\mathrm{CH}_{3}}=51 \mathrm{kcal} / \mathrm{mole}$ and $\mathrm{D}_{\mathrm{Hg}-\mathrm{CH}_{3}}=8 \mathrm{kcal} / \mathrm{mole}$.

Hardly any single metal-alkyl bond dissociation energies in complex transition metal alkyls of the type $L_{n} M-R\left(L=C 0, P R_{3}\right.$, etc.) are known reliably. The 
TABLE 2. Meta1-alkyl bond dissociation energies

\begin{tabular}{lc}
\hline Compound $\left(\mathrm{L}_{\mathrm{n}} \mathrm{M}-\mathrm{R}\right)$ & $\mathrm{D}_{\mathrm{M}-\mathrm{R}}$ (kcal/mole) \\
\hline $\mathrm{Li}\left(\underline{\mathrm{n}}-\mathrm{C}_{4} \mathrm{H}_{9}\right)$ & 57 \\
$\mathrm{Zn}\left(\mathrm{CH}_{3}\right)_{2}$ & 41 (mean) \\
$\mathrm{Cd}\left(\mathrm{CH}_{3}\right)_{2}$ & 32 (mean) \\
$\mathrm{Hg}\left(\mathrm{CH}_{3}\right)_{2}$ & 29 (mean) \\
$\mathrm{Sn}\left(\mathrm{CH}_{3}\right)_{4}$ & 53 (mean) \\
$\mathrm{Pb}\left(\mathrm{CH}_{3}\right)_{4}$ & 35 (mean) \\
$\mathrm{Ta}\left(\mathrm{CH}_{3}\right)_{5}$ & 62 (mean) \\
$\mathrm{W}\left(\mathrm{CH}_{3}\right)_{6}$ & 38 (mean) \\
$(\mathrm{CO})_{5} \mathrm{Mn}_{3}-\mathrm{CH}_{3}$ & ca 30 \\
\hline
\end{tabular}

thermochemical determination of such bond dissociation energies, i.e., from heats of formation of the parent compounds, usually is not feasible because the heat of formation of the $\mathrm{L}_{\mathrm{n}} \mathrm{M}$. fragment rarely is accessible to measurement. One such determination has yielded a value of ca $30 \mathrm{kcal} / \mathrm{mole}$ for the $\mathrm{Mn}-\mathrm{C}$ bond dissociation energy of $\mathrm{CH}_{3}-\mathrm{Mn}(\mathrm{CO})_{5}$ (17), a surprisingly low value in view of the high apparent stability of this compound. While it is premature to generalize on the basis of such limited data, the pattern of weak metal-alkyl bond dissociation energies does seem to extend also to other compounds of this type.

We have been exploring kinetic approaches to the estimation of metal-alkyl bond dissociation energies. In view of the evidence cited earlier for low activation barriers for the recombination of alkyl radicals with 17 -electron metal complexes (i.e., metal-centered radicals), the activation energies for the homolysis of metal-alkyl bonds should approximate the corresponding bonddissociation energies. The estimation of such activation energies is not always straightforward because of complications arising from accompanying alternative reactions (for example, $\beta$-elimination of olefins, migratory insertion of $\mathrm{CO}$ ligands, etc.) or from secondary reactions of the initiallyproduced alkyl radicals. In certain cases, however, such complications may be circumvented and kinetic methods, of considerable potential generality, may be employed to estimate metal-alkyl bond dissociation energies.

We have applied this approach with apparent success to the estimation of the benzy1-manganese bond dissociation energies in $\mathrm{C}_{6} \mathrm{H}_{5} \mathrm{CH}_{2}-\mathrm{Mn}(\mathrm{CO}) 5$ and in some related compounds of the type, $\mathrm{p}-\mathrm{X}-\mathrm{C}_{6} \mathrm{H}_{4} \mathrm{CH}_{2}-\mathrm{Mn}(\mathrm{CO})_{5}$ and $\mathrm{p}-\mathrm{X}-\mathrm{C}_{6} \mathrm{H}_{4} \mathrm{CH}_{2}-\mathrm{Mn}(\mathrm{CO})_{4}-$ $\left(\mathrm{PR}_{3}\right)$ (18). $\mathrm{C}_{6} \mathrm{H}_{5} \mathrm{CH}_{2}-\mathrm{Mn}(\mathrm{CO}) 5$ reacts cleanly with $\mathrm{H}-\mathrm{Mn}(\mathrm{CO}) 5$ with rates conveniently measurable in the temperature range $40-80^{\circ} \mathrm{C}$, according to the stoichiometry of eq. 14 and the rate-law, eq. 15 , where $k_{15}\left(2.0 \times 10^{-5} \mathrm{sec}^{-1}\right.$ at $45^{\circ} \mathrm{C}$ ) is independent of the concentration of $\mathrm{H}-\mathrm{Mn}(\mathrm{CO}) 5_{5}$. Measurements of the temperature dependence of $\mathrm{k}_{15}$ yield the activation parameters, $\Delta \mathrm{H}^{\ddagger} 15=25$ $\mathrm{kcal} / \mathrm{mole}$ and $\Delta \mathrm{S}^{\ddagger} 15=0$ cal $/ \mathrm{mole} \mathrm{deg}$.

$$
\begin{aligned}
& \mathrm{C}_{6} \mathrm{H}_{5} \mathrm{CH}_{2}-\mathrm{Mn}(\mathrm{CO})_{5}+\mathrm{H}-\mathrm{Mn}(\mathrm{CO})_{5} \longrightarrow \mathrm{C}_{6} \mathrm{H}_{5} \mathrm{CH}_{3}+\mathrm{Mn}_{2}(\mathrm{CO})_{10} \\
& \text { RATE }=\mathrm{k}_{15}\left[\mathrm{C}_{6} \mathrm{H}_{5} \mathrm{CH}_{2}-\mathrm{Mn}(\mathrm{CO})_{5}\right]
\end{aligned}
$$

These observations are plausibly interpreted in terms of the mechanistic sequence of eqs. 16-18. 


$$
\begin{aligned}
& \mathrm{C}_{6} \mathrm{H}_{5} \mathrm{CH}_{2}-\mathrm{Mn}(\mathrm{CO})_{5} \stackrel{\mathrm{k}_{15}}{\longrightarrow} \mathrm{C}_{6} \mathrm{H}_{5} \mathrm{CH}_{2} \cdot+\cdot \mathrm{Mn}(\mathrm{CO})_{5} \\
& \mathrm{C}_{6} \mathrm{H}_{5} \mathrm{CH}_{2} \cdot+\mathrm{H}-\mathrm{Mn}(\mathrm{CO})_{5} \stackrel{\text { FAST }}{\longrightarrow} \mathrm{C}_{6} \mathrm{H}_{5} \mathrm{CH}_{3}+\cdot \mathrm{Mn}(\mathrm{CO})_{5} \\
& 2 \cdot \mathrm{Mn}(\mathrm{CO})_{5} \stackrel{\mathrm{FAST}}{\longrightarrow} \mathrm{Mn}_{2}(\mathrm{CO})_{10}
\end{aligned}
$$

The identification of $\Delta \mathrm{H}^{\ddagger}{ }_{15}$ with the $\mathrm{C}_{6} \mathrm{H}_{5} \mathrm{CH}_{2}-\mathrm{Mn}$ (CO) 5 bond dissociation energy, according to this interpretation, yields a value of ca $20-25 \mathrm{kcal} / \mathrm{mole}$ for the latter. This is consistent with the value expected from the thermochemically-determined corresponding bond dissociation enerby ( $30 \mathrm{kcal} / \mathrm{mole}$ ) of $\mathrm{CH}_{3}-\mathrm{Mn}(\mathrm{CO})_{5}$ (17). A puzzling issue that remains to be resolved in connection with this system is the observation that the thermal decomposition of $\mathrm{C}_{6} \mathrm{H}_{5} \mathrm{CH}_{2}-\mathrm{Mn}(\mathrm{CO})_{5}$, in the absence of $\mathrm{H}-\mathrm{Mn}(\mathrm{CO})_{5}$ (or of other radical trapping agents), is much slower than corresponds to k15. This suggests that in the absence of such radical trapping agents, selective recombination of $\mathrm{C}_{6} \mathrm{H}_{5} \mathrm{CH}_{2}$. and $\cdot \mathrm{Mn}(\mathrm{CO})_{5}$ to reform $\mathrm{C}_{6} \mathrm{H}_{5} \mathrm{CH}_{2} \mathrm{Mn}$ (CO) 5 is favored relative to the alternative self-coupling reactions to form $\left(\mathrm{C}_{6} \mathrm{H}_{5} \mathrm{CH}_{2}\right)$ and $\mathrm{Mn}_{2}(\mathrm{CO}) 10$. The reasons for this behavior are presently unclear and the investigation of this and related systems is continuing.

The results of analogous studies (18) on the reaction of $\mathrm{C}_{6} \mathrm{H}_{5} \mathrm{CH}_{2}$ (CO) $\mathrm{Mn}(\mathrm{CO}) 5$ with $\mathrm{H}-\mathrm{Mn}(\mathrm{CO})_{5}$, which proceeds according to the stoichiometry of eq. 22 and with kinetics that are first order in $\mathrm{C}_{6} \mathrm{H}_{5} \mathrm{CH}_{2}(\mathrm{CO})-\mathrm{Mn}(\mathrm{CO})_{5}$ and independent of $\mathrm{H}-\mathrm{Mn}(\mathrm{CO})_{5}\left(\mathrm{k}_{19} \sim 3 \times 10^{-4}\right.$ sec -1 at $\left.45^{\circ} \mathrm{C}\right)$, suggest a similar mechanistic scheme, 1.e., that depicted by eqs. 19-21.

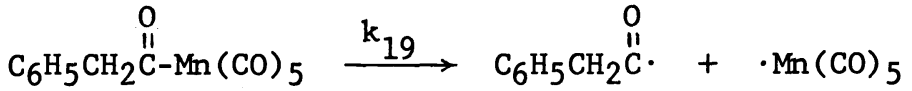

$$
\begin{aligned}
& \left.\mathrm{C}_{6} \mathrm{H}_{5} \mathrm{CH}_{2} \stackrel{0}{\mathrm{C}} \cdot+\mathrm{H}-\mathrm{Mn}(\mathrm{CO})_{5} \stackrel{\mathrm{FAST}}{\longrightarrow} \mathrm{C}_{6} \mathrm{H}_{5} \mathrm{CH}_{2} \stackrel{0}{\mathrm{C}}+\stackrel{\mathrm{H}}{\stackrel{\mathrm{O}}{\mathrm{C}}}+\cdot \mathrm{CO}\right)_{5} \\
& 2 \cdot \operatorname{Mn}(\mathrm{CO})_{5} \stackrel{\text { FAST }}{\longrightarrow} \mathrm{Mn}_{2}(\mathrm{CO})_{10} \\
& \mathrm{C}_{6} \mathrm{H}_{5} \mathrm{CH}_{2} \stackrel{\mathrm{O}}{\mathrm{C}}-\mathrm{Mn}(\mathrm{CO})_{5}+\mathrm{H}-\mathrm{Mn}(\mathrm{CO})_{5} \\
& \mathrm{C}_{6} \mathrm{H}_{5} \mathrm{CH}_{2} \stackrel{\mathrm{O}}{\mathrm{CH}}+\mathrm{Mn}_{2}(\mathrm{CO})_{10}
\end{aligned}
$$

Assuming $\Delta \mathrm{S}^{\ddagger} 19 \sim 0$, yields a value of $\Delta \mathrm{H}^{\ddagger} 19 \sim 24 \mathrm{kcal} / \mathrm{mole}$ which may be identified with the $\mathrm{C}_{6} \mathrm{H}_{5} \mathrm{CH}_{2}(\mathrm{CO})-\mathrm{Mn}(\mathrm{CO}) 5$ bond dissociation energy and, presumably, with other acyl-Mn(CO) 5 bond-dissociation energies.

An important "catalytic" consequence of the weakness of transition metal-alkyl bonds has been identified in a biochemical context, namely that of coenzyme $\mathrm{B}_{12}$-promoted reactions (19-21). Coenzyme $\mathrm{B}_{12}$ ( $5^{\prime}$-deoxyadenosyl cobalamin, abbreviated $\mathrm{RCH}_{2}$-[Co]), representing virtuafly the only class of naturallyoccurring organometallic compounds, serves as a cofactor in a number of biochemical rearrangements a common feature of which (eq. 23) is a 1,2-interchange of a $\mathrm{H}$ atom with a substituent ( $\mathrm{X}=\mathrm{OH}, \mathrm{NH}_{2}$, etc.) on an adjacent carbon atom. A specific example of such a process, the deamination of 1,2-ethanolamine catalyzed by the enzyme ethanolamine ammonia lyasse, is depicted by eq. 24 .

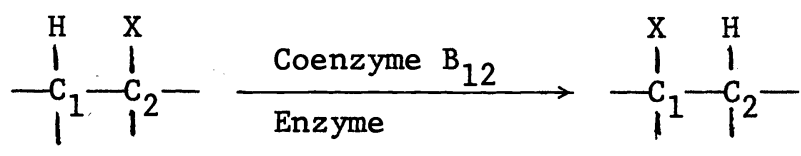




$$
\begin{aligned}
& \underset{\mathrm{NH}_{2} \mathrm{H}}{\mathrm{CH}_{2}-\mathrm{C}-\mathrm{OH}} \frac{\begin{array}{l}
\mathrm{H} \\
\text { Ethanolamine } \\
\text { Ammonia Lyase }
\end{array}}{\mathrm{H}}\left[\begin{array}{c}
\mathrm{CH}_{3}-\underset{\mathrm{C}}{\mathrm{C}}-\mathrm{OH} \\
\mathrm{NH}_{2}^{\mathrm{I}}
\end{array}\right] \\
& \stackrel{-\mathrm{NH}_{3}}{\longrightarrow} \mathrm{CH}_{3} \stackrel{\stackrel{\mathrm{O}}{\prime \prime}-\mathrm{H}}{\longrightarrow}
\end{aligned}
$$

A considerable body of evidence has accumulated in support of the mechanistic scheme depicted below for these reactions. This mechanism encompasses the following sequence of steps: (i) enzyme-induced homolysis of the cobaltcarbon bond of the coenzyme to generate vitamin $\mathrm{B}_{12}$ [i.e., cobalamin(II)] and a $5^{\prime}$-deoxyadenosyl radical (abbreviated $\mathrm{RCH}_{2} \cdot \mathrm{F}^{2} \mathrm{r}$ (ii) $\mathrm{H}$-atom abstraction from the substrate by $\mathrm{RCH}_{2}$ ' to generate a substrate radica1 and $5^{\prime}-\mathrm{deoxy}-$ adenosine $\left(\mathrm{RCH}_{3}\right)$, (iii) rearrangement of the resulting substrate radical (through a mechanism which is not fully understood and which probably differs from substrate to substrate), and (iv) abstraction of a $\mathrm{H}$-atom from $\mathrm{RCH}_{3}$ by the rearranged substrate radical to complete the rearrangement reaction (19-21).

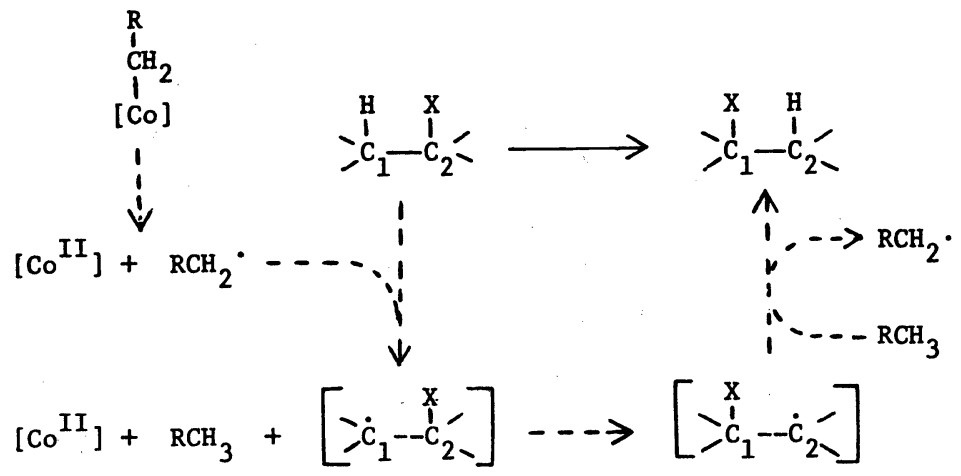

According to this the principal role of the organometallic cofactor in these reactions, $i . e .$, of coenzyme $B_{12}$, is to serve as a precursor for an organic free radical, a role associated with the characteristic weakness of the transition metal-alkyl bond.

\section{FREE RADICAL MECHANISMS OF HYDROGENATION}

Some of the available data concerning metal-hydrogen bond dissociation energies are summarized in Table 3. Two types of data are included, namely (i) dissociation energies of gaseous diatomic hydrides which can be deduced from spectroscopic measurements, and (ii) $\mathrm{M}-\mathrm{H}$ bond dissociation energies of some complex hydrides, deduced from measurements of the temperature-dependence of reversible reactions with $\mathrm{H}_{2}$ (e.g., eqs. 25-27).

$$
\begin{aligned}
& 2\left[\mathrm{Co}(\mathrm{CN})_{5}\right]^{3-}+\mathrm{H}_{2} \rightleftarrows 2\left[\mathrm{HCo}(\mathrm{CN})_{5}\right]^{3-} \\
& {\left[\mathrm{Co}_{2}(\mathrm{CO})_{8}\right]+\mathrm{H}_{2} \rightleftarrows 2\left[\mathrm{HCo}(\mathrm{CO})_{4}\right]} \\
& {\left[\operatorname{IrCl}(\mathrm{CO})\left(\mathrm{PPh}_{3}\right)_{2}\right]+\mathrm{H}_{2} \rightleftarrows\left[\mathrm{IrH}_{2} \mathrm{Cl}(\mathrm{CO})\left(\mathrm{PPh}_{3}\right)_{2}\right]}
\end{aligned}
$$


TABLE 3. Meta1-hydrogen bond dissociation energies

\begin{tabular}{|c|c|}
\hline Compound $\left(L_{n} M-H\right)$ & $\mathrm{D}_{\mathrm{M}-\mathrm{H}}(\mathrm{kcal} / \mathrm{mole})$ \\
\hline${ }^{[\mathrm{H}-\mathrm{Li}] \mathrm{g}}$ & $\sim 58$ \\
\hline${ }^{[\mathrm{H}-\mathrm{Na}]} \mathrm{g}$ & 47 \\
\hline${ }^{[\mathrm{H}-\mathrm{A} I]} \mathrm{g}$ & 67 \\
\hline$[\mathrm{H}-\mathrm{Ni}] \mathrm{g}$ & $\sim 60$ \\
\hline${ }^{[\mathrm{H}-\mathrm{Cu}]} \mathrm{g}$ & 66 \\
\hline${ }^{[\mathrm{H}-\mathrm{Ag}]} \mathrm{g}$ & 58 \\
\hline${ }^{[\mathrm{H}-\mathrm{Au}]} \mathrm{g}$ & 72 \\
\hline$\left[\mathrm{H}-\mathrm{Co}(\mathrm{CO})_{4}\right]$ & 58 \\
\hline$\left[\mathrm{H}-\mathrm{Co}(\mathrm{CN}) 5^{3-}\right] \mathrm{aq}$ & 58 \\
\hline$\left[\mathrm{H}_{2}-\operatorname{IrCl}(\mathrm{CO})\left(\mathrm{PPh}_{3}\right)_{2}\right]$ & 60 (mean) \\
\hline
\end{tabular}

Most of the M-H bond dissociation energies 1isted in Table 3 are close to 60 $\mathrm{kcal} / \mathrm{mole}$, a value which appears to be relatively insensitive to quite marked variations of the nature of the metal and of the other ligands. Using this typical value for the $\mathrm{L}_{\mathrm{n}} \mathrm{M}-\mathrm{H}$ bond dissociation energy and the known heats of formation of the ethyl and phenylethyl free radical products, the enthalpies of reactions (28) and (29) can be estimated to be ca 25 and $15 \mathrm{kcal} / \mathrm{mole}$, respectively. Corresponding estimates for the transfer of H-atoms from metal hydrides to other unsaturated molecules are listed in Table 4. As previously noted (cf. Fig. 1) the activation barriers for the reverse reactions (e.g., $\mathrm{L}_{\mathrm{n}} \mathrm{M} \cdot+\mathrm{RCH}_{2} \mathrm{CH}_{2} \cdot \longrightarrow \mathrm{I}_{\mathrm{n}} \mathrm{M}-\mathrm{H}+\mathrm{RCH}=\mathrm{CH}_{2}$, etc.) are typically small and therefore the activation enthalpies of reactions such as (28) and (29) are expected to be close to the corresponding enthalpies of reaction.

$$
\begin{aligned}
& \mathrm{L}_{n} \mathrm{M}-\mathrm{H}+\mathrm{CH}_{2} \mathrm{CH}_{2} \longrightarrow \mathrm{L}_{n} \mathrm{M} \cdot+\mathrm{CH}_{3} \mathrm{CH}_{2} \cdot \\
& \mathrm{L}_{n} \mathrm{M}-\mathrm{H}+\mathrm{C}_{6} \mathrm{H}_{5} \mathrm{CH}=\mathrm{CH}_{2} \longrightarrow \mathrm{L}_{n} \mathrm{M} \cdot+\mathrm{C}_{6} \mathrm{H}_{5} \dot{\mathrm{CHCH}}_{3}
\end{aligned}
$$

The estimated activation enthalpy of reaction (29), i.e., ca $15-20 \mathrm{kcal} / \mathrm{mole}$, is sufficiently low that this process is expected to occur with appreciable rates at moderate temperatures, below $100^{\circ} \mathrm{C}$. This has been confirmed in studies on the hydrogenation of $\alpha$-methylstyrene by $\mathrm{HMn}(\mathrm{CO})_{5}$ which has been shown, by application of the CIDNP technique as well as by kinetic and isotopic tracer measurements, to proceed through the mechanistic sequence of eqs. 30-32 (9).

$$
\begin{aligned}
& \mathrm{CH}_{2}=\mathrm{C}\left(\mathrm{CH}_{3}\right) \mathrm{C}_{6} \mathrm{H}_{5}+\mathrm{HMn}(\mathrm{CO})_{5} \stackrel{\mathrm{k}_{30}}{\longrightarrow}\left(\mathrm{CH}_{3}\right)_{2} \dot{\mathrm{C}}_{6} \mathrm{H}_{5}+\cdot \mathrm{Mn}(\mathrm{CO})_{5} \\
& \left(\mathrm{CH}_{3}\right)_{2} \dot{\mathrm{CC}}_{6} \mathrm{H}_{5}+\mathrm{HMn}(\mathrm{CO})_{5} \stackrel{\mathrm{FAST}}{\longrightarrow}\left(\mathrm{CH}_{3}\right)_{2} \mathrm{CHC}_{6} \mathrm{H}_{5}+\cdot \mathrm{Mn}(\mathrm{CO})_{5} \\
& 2 \cdot \mathrm{Mn}(\mathrm{CO})_{5} \stackrel{\mathrm{FAST}}{\longrightarrow} \mathrm{Mn}_{2}(\mathrm{CO})_{10} \\
& \mathrm{CH}_{2}=\mathrm{C}\left(\mathrm{CH}_{3}\right) \mathrm{C}_{6} \mathrm{H}_{5}+2 \mathrm{HMn}(\mathrm{CO})_{5} \longrightarrow\left(\mathrm{CH}_{3}\right)_{2} \mathrm{CHC}_{6} \mathrm{H}_{5}+\mathrm{Mn}_{2}(\mathrm{CO})_{10}
\end{aligned}
$$

The hydrogenation of anthracene to 9,10-dihydroanthracene by metal hydrides such as $\mathrm{H}-\mathrm{Mn}(\mathrm{CO})_{5}$ or $\mathrm{H}-\mathrm{Co}(\mathrm{CO})_{4}$, which proceeds readily at temperatures in the 
TABLE 4. Estimated enthalpies of some reactions involving $\mathrm{H}$-atom transfer from metal hydrides to unsaturated molecules

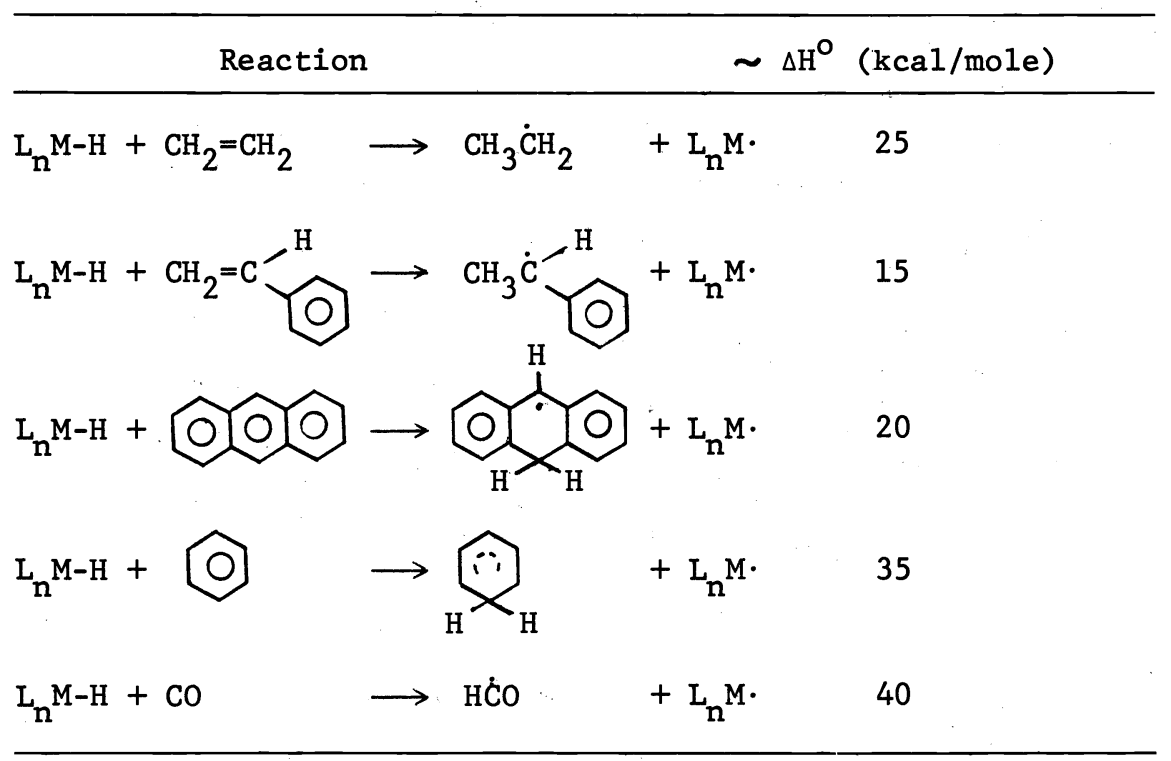

vicinity of $100^{\circ} \mathrm{C}(22)$, can be accommodated by a similar mechanistic sequence, i.e.,

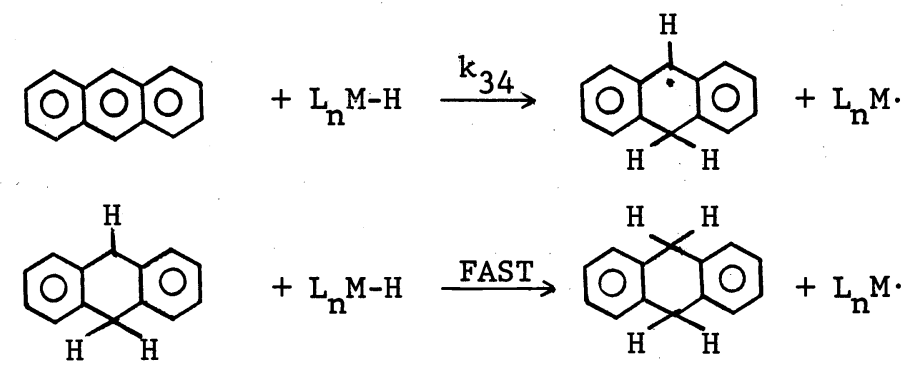

$2 \mathrm{~L}_{\mathrm{n}} \mathrm{M} \cdot \stackrel{\text { FAST }}{\longrightarrow} \mathrm{M}_{2} \mathrm{~L}_{2 \mathrm{n}}$

$$
\text { OOOO }+2 \mathrm{~L}_{\mathrm{n}-\mathrm{H}}^{\mathrm{M}} \rightarrow
$$

The use of $\mathrm{H}-\mathrm{Mn}(\mathrm{CO})_{5}$ as a catalyst for hydrogenation by $\mathrm{H}_{2}$ through mechanisms incorporating such steps is constrained by the high temperatures ( $>200^{\circ} \mathrm{C}$ ) required to regener ate $\mathrm{H}-\mathrm{Mn}(\mathrm{CO})_{5}$ by reaction of $\mathrm{H}_{2}$ with $\mathrm{Mn}_{2}(\mathrm{CO}) 10$. In the case of certain other metal hydride complexes, for example $\mathrm{HCo}(\mathrm{CO}) 4$ and $\mathrm{HCo}(\mathrm{CN}) 5^{3}$, regeneration by reaction of $\mathrm{H}_{2}$ with the corresponding dehydrogenated complexes (i.e., $\mathrm{Co}_{2}(\mathrm{CO})_{8}$ and $\mathrm{Co}(\mathrm{CN}) 5^{3-}$, respectively) occurs under milder conditions so that catalytic cycles corresponding to the overall hydrogenation reaction (38) and encompassing the reaction sequence (34)-(37), followed by reaction $(39)$, can be achieved $(23,8)$. 


$$
\mathrm{M}_{2} \mathrm{~L}_{2 \mathrm{n}}\left(\text { or } 2 \mathrm{ML}_{\mathrm{n}}\right)+\mathrm{H}_{2} \longrightarrow 2 \mathrm{H}-\mathrm{ML}_{\mathrm{n}}
$$

The kinetics and distinctive selectivity patterns of the $\mathrm{HCo}(\mathrm{CO}) 4$-catalyzed homogeneous hydrogenation of polycyclic arenes (e.g., the selective hydrogenation of naphthalene to tetralin) have recently been interpreted in terms of such free radical mechanisms (8). Analogous mechanisms have previously been invoked for the $\mathrm{HCo}(\mathrm{CN}) 5^{3-}$-catalyzed hydrogenation of styrene and of $\alpha, \beta$-unsaturated olefinic compounds (24-27).

Recently, Rathke and Feder (28) have described the HCo(CO) 4 -catalyzed hydrogenation of $C O$ to yield, as primary products, methanol and methyl formate which are converted through further homologation reactions to higher alcohols and esters. The observed activation energy for this reaction, i.e., 41 $\mathrm{kcal} / \mathrm{mole}$, is close to the enthalpy of reaction (40) (cf. Table 4) possibly implying a free radical mechanism involving this reaction as a step (28). Whatever the mechanism, this system encompasses the first demonstration of a mononuclear catalyst for the homogeneous hydrogenation of $\mathrm{CO}$.

$$
\mathrm{H}-\mathrm{Co}(\mathrm{CO})_{4}+\mathrm{CO} \longrightarrow \mathrm{HC} \mathrm{O}+\cdot \mathrm{Co}(\mathrm{CO})_{4}
$$

These examples of the hydrogenation of olefins, arenes and co, illustrate the widespread demonstrated and potential roles of free radical mechanisms, initiated by $\mathrm{H}$-atom transfer from metal hydrides to unsaturated substrates, in homogeneous catalytic hydrogenation and related processes. Furthermore, the considerations discussed prompt reconsideration of certain reactions which have previously been interpreted in terms of other mechanisms. One such case is that of the $\mathrm{HCo}(\mathrm{CO})_{4}$-catalyzed hydrogenation of arenes, interpreted above in terms of the mechanistic sequence of eqs. $34,35,36$ and 38 , which had previously (29) been interpreted in terms of an alternative mechanism involving organometallic intermediates formed by "concerted" addition of $\mathrm{Co}-\mathrm{H}$ to the arene. Another case that warrants reexamination is the hydroformylation reaction (eq. 41) which is generally interpreted in terms of the mechanistic sequence depicted in Table 1 , involving coordination of the olefin to the cobalt atom, insertion into the Co-H bond to form an alkyl-cobalt complex, insertion of $C O$ into the resulting cobalt-carbon bond to form an acyl-cobalt complex, and "hydrogenolysis" of the latter to regenerate the starting cobalt hydride.

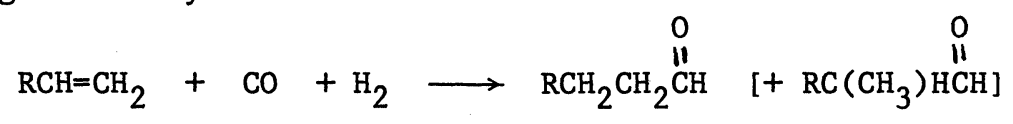

While there is no reason to question the validity of such a mechanism in the case of "simple" olefins such as propylene, its applicability to the hydroformylation of styrene (and, correspondingly, to $\alpha, \beta$-unsaturated compounds) is open to serious question. Our earlier estimate of ca $15-20 \mathrm{kcal} / \mathrm{mole}$ for the activation energy of reaction (29) suggests that such a process should be occurring for styrene and related olefins under typical hydroformylation conditions (i.e., ca $100-150^{\circ} \mathrm{C}$ ) at rates of the order of those observed for hydroformylation and competitive with those of the "conventional" hydroformylation mechanism. This suggests an alternative free-radical mechanistic pathway for hydroformylation which is elaborated in Fig. 2.

This scheme, as applied to an olefin such as styrene, predicts several distinctive results which do not follow readily from the alternative "conventional" mechanism, namely (i) a higher olefin-hydrogenation to hydroformylation ratio, (ii) a higher ratio of methyl-branched to normal aldehyde, and (iii) the production of optically active aldehyde but essentially racemic hydrocarbon (i.e., hydrogenation product) when a prochiral olefin such as $\alpha$-ethylstyrene is reacted with $\mathrm{CO}$ and $\mathrm{H}_{2}$ in the presence of a chiral hydroformylation catalyst. All three of these predictions are consistent with the results reported for the hydroformylation of styrene and related substrates $(30)$.

Finally it should be noted that the results of the studies cited earlier pertaining to reactions (19)-(22) suggest a plausible mechanism, represented by eqs. 42-44, for the final stage of the conventional cobalt carbonyl-catalyzed hydroformylation reaction sequence (i.e., the generation of aldehyde from the 


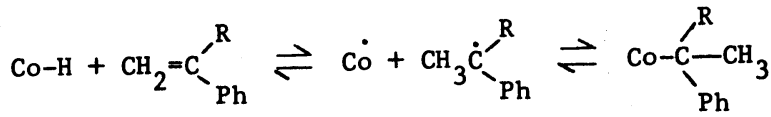

$$
\begin{aligned}
& \downarrow \text { Co-H } \downarrow^{\mathrm{CO}} \\
& \mathrm{CH}_{3} \overbrace{\mathrm{Ch}}^{\mathrm{H}}
\end{aligned}
$$

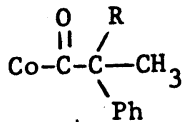

$$
\begin{aligned}
& \downarrow_{[\mathrm{H}]}^{\mathrm{Ph}}
\end{aligned}
$$

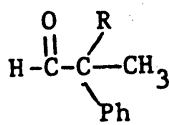

Fig. 2. Proposed mechanism of hydroformylation of styrene.

acyl-cobalt intermeidate) about which there is still some uncertainty.

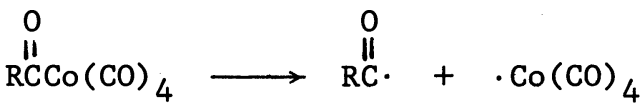

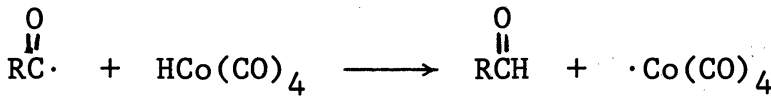

$$
\begin{aligned}
& 2 \cdot \mathrm{Co}(\mathrm{CO})_{4} \rightleftarrows \mathrm{Co}_{2}(\mathrm{CO})_{8} \stackrel{\mathrm{H}_{2}}{\rightleftarrows} 2 \mathrm{HCo}(\mathrm{CO})_{4}
\end{aligned}
$$

Acknowledgment - The material discussed in this paper encompasses the research and unpublished results of several coworkers, notably R. L. Sweany, M. J. H. Russe11, S. Diefenbach and S. Butler, whose contributions are gratefully acknowledged. Appreciation also is expressed to Drs. H. M. Feder and J. W. Rathke of the Argonne National Laboratory for valuable and stimulating discussions. This research was supported by grants from the National Science Foundation (CHE78-01192) and the National Institutes of Health (AM-13339).

\section{REFERENCES}

1. J. Chatt and J. Halpern, in "Catalysis: Progress in Research," F. Basolo and R. Burwe11, Eds., Plenum Press, New York (1973) pp. $107-129$.

2. J. Halpern, in "Organic Synthesis via Metal Carbonyls," Vol. II, I. Wender and P. Pino, Eds., John Wiley and Sons, New York (1977) pp. 705-730, and references therein.

3. J. Halpern, Trans. Amer. Cryst. Assoc., 14, 59-70 (1978), and references therein.

4. For a review of the scope and of some mechanistic aspects of industrially important homogeneous catalytic processes, see: G. W. Parshall, J. Molec. Catalysis, $4,243-270$ (1978). 
5. B. D. Vineyard, W. S. Knowles, M. J. Sabacky, G. L. Bachman and D. J. Weinkauff, J. Amer. Chem. Soc., 99, 5947-5972 (1977), and references therein. H. Kagan and J. C. Fiaud, Top. Stereochem., 10, 175-285 (1978), and references therein.

6. M. F. Lappert and P. W. Lednov, Adv. Organomet. Chem., 14, 345-399 (1976), and references therein.

7. J. K. Kochi, Acc. Chem. Res., 7, 351-360 (1974), and references therein.

8. H. M. Feder and J. Halpern, J. Amer. Chem. Soc., 97, 7186-7188 (1975).

9. R. L. Sweany and J. Halpern, J. Amer. Chem. Soc., 99, 8335-8337 (1977).

10. C. E. Castro and W. C. Kray, Jr., J. Amer. Chem. Soc., 85, 2768-2772 (1963). J. K. Kochi and D. D. Davis, J.Amer. Chem. Soc., $\underline{86}$, 5264-5271 (1964).

11. J. Halpern and J. P. Maher, J. Amer. Chem. Soc., 86, 2311 (1964); 87, 5361-5365 (1965).

12. P. B. Chock and J. Halpern, J. Amer. Chem. Soc., 90, 6959-6963 (1968).

13. P. W. Schneider, P. F. Phelan and J. Halpern, J. Amer. Chem. Soc., 91, 77-81 (1969).

14. J. Halpern and P. Phelan, J. Amer. Chem. Soc., 94, 1881-1886 (1972).

15. L. G. Marzilli, P. A. Marzilli and J. Halpern, J. Amer. Chem. Soc., 92, $5752-5753$ (1970); 93, 1374-1378 (1971).

16. J. A. Connor, Topics in Current Chemistry, 71, 71-110 (1977), and references therein.

17. D. L. S. Brown, J. A. Connor and H. A. Skinner, J. Organomet. Chem., 81, 403-409 (1974).

18. J. Halpern, R. L. Sweany, M. J. H. Russell and S. Diefenbach, unpublished results.

19. J. Halpern, Ann. N. Y. Acad. Sci., 239, 2-21 (1974).

20. B. M. Babior, Acc. Chem. Res., 8, 376-384 (1975).

21. R. H. Abeles and D. Dolphin, Acc. Chem. Res., 9, 114-120 (1976).

22. J. Halpern, R. L. Sweany and S. Butler, unpublished results.

23. S. Friedman, S. Metlin, A. Svedi and I. Wender, J. Org. Chem., 24, 1287-1289 (1959).

24. J. Kwiatek, Catalysis Revs., 1, 37-72 (1968). J. Kwiatek and J. K. Seyler, Adv. Chem. Ser., 70, 207-232 (1968).

25. J. Halpern and L. Y. Wong, J. Amer. Chem. Soc., 90, 6665-6669 (1968).

26. L. Simandi and F. Nagy, Acta Chim. Hung., 46, 137-148 (1965).

27. W. Stroheimer and N. Iglauer, Z. Physik. Chem. (Frankfurt), 51, 50-57 (1966).

28. J. W. Rathke and H. M. Feder, J. Amer. Chem. Soc., 100, 3623-3625 (1978).

29. P. D. Taylor and M. Orchin, J. Org. Chem., 37, 3913-3915 (1972).

30. P. Pino, F. Piacenti and M. Bianchi, in "Organic Synthesis via Metal Carbonyls," Vol. II, I. Wender and P. Pino, Eds., John Wiley and Sons, New York (1977), pp. 43-231, and references therein. 